\title{
Improving the management of threatened ecosystems in an urban biodiversity hotspot through the Durban Research Action Partnership
}

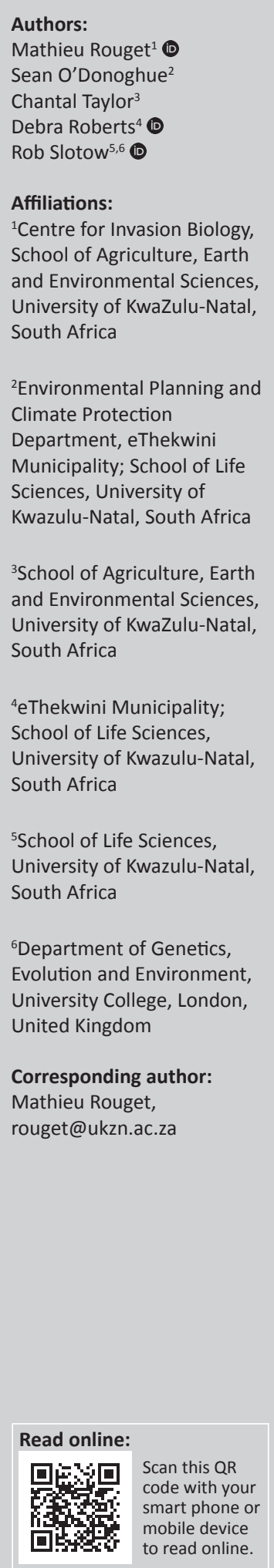

Cities have a vital role to play in managing biodiversity and dealing with global environmental change issues (de Oliviera et al. 2011; Gilbert et al. 2013). It is projected that, by 2030, global urban land area will have nearly tripled, making the next two decades the most rapid period of urbanisation in the world's history. This development will increase global carbon emissions and result in a 'considerable loss of habitats in key biodiversity hotspots' (Seto et al. 2012). Africa currently displays the fastest rate of urban growth in the world (Pieterse \& Parnell 2016) and there are predictions of significant urban migrations over the next decades (UN-HABITAT 2010). It is critical that this development follows a low-carbon and climate-resilient pathway if the ambitions of the Paris Agreement to limit global temperature increase to well below $2{ }^{\circ} \mathrm{C}$ are to be realised.

Global change, through land use and climate change, has a profound effect on biodiversity, resulting in changes in ecosystem functioning, the extent of natural habitats and species distribution (Sala et al. 2000). Cities therefore have a critical role in managing the effects of global change on biodiversity (Grimm et al. 2008). In South Africa, the city of Durban, which is governed by the eThekwini Municipality, has developed several innovative mechanisms to address climate change and reduce biodiversity loss (Roberts et al. 2012).

Durban, the third largest city in South Africa, has the highest percentage nationally of people living in poverty (EThekwini Municipality 2013b), and high levels of inequality, with a Gini coefficient of 0.63 in 2012 (EThekwini Municipality 2015). The eThekwini metropolitan area is characterised by large portions of rural and peri-urban land uses (EThekwini Municipality 2013a). Large areas of tribal land, governed by traditional leaders who employ traditional governance systems, have been incorporated into the city's boundaries, resulting in dual governance systems of tribal land in areas adjacent to wards with democratically elected councillors subject to formal town planning schemes. Durban is located in the MaputalandPondoland-Albany Region, one of 35 global biodiversity hotspots (Mittermeier et al. 2005), with more than 7000 species of vascular plants, $25 \%$ of which are endemic to the region (van Wyk \& Smith 2001). Owing to its varied climate, physiography, lithology, soils and biogeographical position, a wide range of terrestrial and aquatic ecosystems that support a rich biodiversity occur in the eThekwini Municipality.

After several years of interaction between the Environmental Planning and Climate Protection Department (EPCPD) of eThekwini Municipality (EM) and the University of KwaZulu-Natal (UKZN), a research programme was initiated in 2011 as a joint initiative to address environmental challenges pertaining to global change within Durban (Cockburn et al. 2016). The research programme focused on a poorly understood but threatened ecosystem - the KwaZulu-Natal Sandstone Sourveld (KZNSS) - to address biodiversity and climate change issues, to build capacity and to improve the planning and management of biodiversity in Durban.

The perceived success of the KZNSS research programme by both institutions led to the establishment of the Durban Research Action Partnership (D'RAP). The partnership was developed to advance knowledge in biodiversity conservation and management within the context of global environmental change. Through the partnership, collaborative research is conducted within Durban in a range of disciplines including environmental, biological and

How to cite this article: Rouget, M., O'Donoghue, S., Taylor, C., Roberts, D. \& Slotow, R., 2016, 'Improving the management of threatened ecosystems in an urban biodiversity hotspot through the Durban Research Action Partnership', Bothalia 46(2), a2199. http://dx.doi. org/10.4102/abc.v46i2.2199

Copyright: @ 2016. The Authors. Licensee: AOSIS. This work is licensed under the Creative Commons Attribution License. 
social science, governance and economics. D'RAP aims to generate much-needed knowledge to assist managers in EM to make biodiversity and conservation decisions, and to build capacity by employing interns and supporting student research activities at UKZN. Such novel institutional partnerships are important for generating knowledge and learning outcomes, so as to address the gap between scientific research, policy development and management within a local government setting. Similar initiatives focused on the science-policy-practice interface are emerging in several African cities, for example the Future Resilience for African Cities and Lands (FRACTAL) project, which aims to improve the implementation of climate science at a local government level, working in Southern African cities such as Windhoek, Lusaka, Maputo, Cape Town and Durban (http: / / www.fractal.org.za/ and http://www.futureclimateafrica. $\operatorname{org} /)$.

The engagement between the EM and UKZN has resulted in the completion of three municipally funded internships aimed at increasing critically scarce skills and capacity in this field; two of these internships resulted in permanent appointments within the EPCPD. Since its inception in 2011, the D'RAP partnership has developed a transdisciplinary approach with co-creation of research from design to completion of research products and uptake into policy, planning and management. Both parties (UKZN and EM) are involved in developing research questions, conducting research and integrating the research into practice. Most research has been conducted through postgraduate students registered at UKZN. In this special issue of Bothalia, African Biodiversity \& Conservation, we present some of the findings of the research emerging from the first programme of D'RAP the KZNSS research programme. Papers presented represent some of the outputs of this research partnership. Whilst little was known of the KZNSS in 2011, a series of publications, reports, management tools and data sets have been produced a few years later to address this hiatus. Much of the research output by the KZNSS programme, however, remained unusable for officials in the EPCPD. This hiatus highlights the difference in culture, organisation and working environment between the two organisations and is one of the challenges of transdisiplinary research programmes (Taylor et al. 2016). In response, D'RAP funded the 'translation' of the research outputs into working and popular documents that were more accessible to EPCPD staff and the general public. This step is considered to have been important in the transdisciplinary research process and will facilitate better management of this ecosystem by EPCPD staff.

The papers cover a range of topics from managing threatened ecosystems (Boon et al. 2016), improving our understanding of plant diversity (Drury et al. 2016; Ground et al. 2016), quantifying pressures and threats (Buhrmann et al. 2016; Buthelezi et al. 2016; Naicker et al. 2016; Odindi et al. 2016), understanding community benefits, governance and value (Davids et al. 2016; Nkambule et al. 2016; Sutherland et al. 2016), to evaluating the outcomes of this transdisciplinary research programme (Taylor et al. 2016).
Much of the biodiversity of the KZNSS ecosystem, and how to manage it, is poorly understood. The first three papers contribute to improving our knowledge in this regard. Boon et al. (2016) provide an overview of the KZNSS ecosystem in Durban and describe some of the work that EM is undertaking in Durban to secure and manage this threatened ecosystem and other biodiversity values. They also highlight some challenges that will have to be overcome to improve levels of protection and management. Drury et al. (2016) examine the variation in plant diversity (alpha and beta diversity) across patches of KZNSS in order to differentiate it from adjacent similar vegetation types. Ground et al. (2016) further assess the variation in forb species richness to improve land-use decision-making, especially the use of systematic conservation planning to select and manage key grassland sites.

The biodiversity of the KZNSS ecosystem is threatened by several processes, including habitat loss and fragmentation, biological invasions and woody encroachment, inappropriate fire regimes and climate change. Naicker et al. (2016) have quantified the overall level of habitat fragmentation and connectivity using graph theory. They developed an approach to select key patches within the municipal area, contributing significantly to the overall connectivity of this threatened ecosystem. Odindi et al. (2016) highlight the potential of new generation satellite imagery, such as RapidEye, to detect and quantify woody encroachment, one of the key landscape processes affecting the biodiversity of the KZNSS. Using a 10-year time series of fire extent, Buthelezi et al. (2016) quantified changes in fire regimes over the years and compared the fire regimes of the KZNSS vegetation type with surrounding vegetation types. Lastly, Buhrmann et al. (2016) provide one of the first on-site assessments of elevated temperatures on South African grasslands using open-top chambers to simulate and predict the effects of climate change on plant productivity and ecosystem functioning.

Successful biodiversity conservation requires an understanding of the benefits, values and perceptions of biodiversity in relation to the community. This aspect has been addressed in various ways in the KZNSS research programme. Davids et al. (2016) provide an assessment of ecosystem services in Durban, maps of ecosystem services hotspots and identify opportunities for securing a sustainable supply of ecosystem services. Sutherland et al. (2016) focus on the intertwined issues of rapid urban growth, dual governance systems, biodiversity loss and cultural change in Mzinyathi and eSkebheni in the north-west of Durban. They explore the numerous social constructions of environmental services and the implications for resilience in the area. Nkambule et al. (2016) examine the uses, perceptions and attitudes displayed by the iNanda community towards the KZNSS grassland, in order to inform the potential use of community-based conservation strategies.

Finally, Taylor et al. (2016) present a continuous reflective evaluation of the successes and challenges of the partnership in terms of research outputs and outcomes, opportunity for 
translation of the research into practice, and perceptions of the partnership by the participants.

The papers in this special issue contribute to a greater understanding of the KZNSS ecosystem and its drivers of change. They pave the way for improved management of this threatened ecosystem in Durban and beyond, and highlight the crucial role that research-action partnerships can play to address contemporary environmental challenges. Such a case study provides insights that may be useful to local governments, in particular those in developing countries, which are located in bio-diverse areas or with threatened ecosystems in their jurisdictions. Whilst the papers bring together a substantial body of work on a relatively unknown, important, and threatened habitat type, and provide biological and sociological foundational understanding, translation of the work into practical application within the policy and procedures of the municipality has been challenging. The D'RAP emerged as a mechanism to facilitate such translation (Cockburn et al. 2016), and is itself a product of this body of work. We emphasise the importance of putting in place such mechanisms to ensure translation of the research outcomes into practice, so that the true value of the knowledge and understanding generated is fully achieved.

\section{Acknowledgements}

This research is supported by eThekwini Municipality through the Durban Research Action Partnership: KwaZuluNatal Sandstone Sourveld Programme, together with the South African Research Chairs Initiative of the Department of Science and Technology and the National Research Foundation of South Africa (grant no. 84157).

\section{Competing interests}

The authors declare that they have no financial or personal relationships which may have inappropriately influenced them in writing this article.

\section{Author's contribution}

M.R. wrote the first draft. All other authors contributed to the subsequent drafts.

\section{References}

Boon, R., Cockburn, J., Douwes, E., Govender, N., Ground, L., Mclean, C. et al., 2016 'Managing a threatened savanna ecosystem (KwaZulu-Natal Sandstone Sourveld) in an urban biodiversity hotspot: Durban, South Africa', Bothalia: African Biodiversity \& Conservation 46(2). http://dx.doi.org/10.4102/abc.v46i2.2112

Buhrmann, R., Ramdhani, S., Pammenter, N. \& Sershen, N., 2016, 'Grasslands feeling the heat: The effects of elevated temperatures on a sub-tropical grassland' Bothalia: African Biodiversity \& Conservation 46(2). http://dx.doi.org/10.4102/ abc.v46i2.2122
Buthelezi, N., Mutanga, O., Sinanda, M. \& Rouget, M., 2016, 'A Spatial and temporal assessment of fire regimes on different vegetation types using MODIS burnt area products', Bothalia: African Biodiversity \& Conservation 46(2). http://dx.doi. products', Bothalia: African
org/10.4102/abc.v46i2.2148

Cockburn, J., Rouget, M., Slotow, R., Roberts, D., Boon, R., Douwes, E. et al., 2016, 'How to build science-action partnerships for local land use planning and management: Lessons from Durban, South Africa', Ecology and Society 21(1), 28. management: Lessons from Durban, South
http://dx.doi.org/10.5751/ES-08109-210128

Davids, R., Rouget, M., Boon, R. \& Roberts, D., 2016, 'Identifying ecosystem service hotspots for environmental management in Durban, South Africa', Bothalia: African Biodiversity \& Conservation 46(2). http://dx.doi.org/10.4102/abc.v46i2. 2118

de Oliveira, J.P., Balaban, O., Doll, C.N., Moreno-Peñaranda, R., Gasparatos, A lossifova, D. et al.,2011, "Cities and biodiversity: Perspectives and governance challenges for implementing the convention on biological diversity (CBD) at the challenges for implementing the convention on biological diversity (CBD) at the
city level', Biological Conservation 144(5), 1302-1313. http://dx.doi.org/10.1016/ j.biocon.2010.12.007

Drury, C., Ramdhani, S., Sershen, N., Carbutt, C., Boodhraj, R. \& Mbatha, P., 2016, 'Floristics of KwaZulu-Natal Sandstone Sourveld within the eThekwini Municipal Area', Bothalia: African Biodiversity \& Conservation 46(2).

EThekwini Municipality, 2013a, Integrated Development Plan (IDP) annual review 2013/2014, EThekwini Municipality, Durban.

EThekwini Municipality, 2013b, Economic development and job creation strategy, EThekwini Municipality, Durban.

EThekwini Municipality, 2015, EThekwini Municipality integrated development plan 2015/2016, EThekwini Municipality, Durban.

Gilbert, R., Stevenson, D., Girardet, H. \& Stren, R., 2013, Making cities work: Role of local authorities in the urban environment, Earthscan, London.

Grimm, N.B., Faeth, S.H., Golubiewski, N.E., Redman, C.L., Wu, J., Bai, X. et al., 2008 'Global change and the ecology of cities', Science 319(5864), 756-760. http:// dx.doi.org/10.1126/science.1150195

Ground, L., Slotow, R. \& Mukherjee, J., 2016, 'Threatened grassland diversity persists in a municipality within a global hotspot', Bothalia: African Biodiversity \& Conservation 46(2). http://dx.doi.org/10.4102/abc.v46i2.2106

Mittermeier, R.A., Gil, P.R., Hoffman, M., Pilgrim, J. \& Brooks, T., 2005, Hotspots revisited: Earth's biologically richest and most endangered terrestrial ecosystems, Conservation International, Arlington, VA.

Naicker, R., Rouget, M. \& Mutanga, O., 2016, 'Assessing habitat fragmentation of the KwaZulu-Natal Sandstone Sourveld, a threatened ecosystem', Bothalia: African Biodiversity \& Conservation 46(2). http://dx.doi.org/10.4102/abc.v46i2.2104

Nkambule, S., Buthelezi, H. \& Munien, S., 2016, 'Opportunities and constraints for community-based conservation: The case of the KwaZulu-Natal Sandstone Sourveld grassland, South Africa', Bothalia: African Biodiversity \& Conservation 46(2). http://dx.doi.org/10.4102/abc.v46i2.2120

Odindi, J., Mutanga, O., Rouget, M. \& Hlanguza, N., 2016, 'Mapping alien and indigenous vegetation in the KwaZulu-Natal Sandstone Sourveld using remotely sensed data', Bothalia: African Biodiversity \& Conservation 46(2). http://dx.doi org/10.4102/abc.v46i2.2103

Pieterse, E. \& Parnell, S., 2014, 'Africa's urban revolution in context', in S. Parnell \& E. Pieterse (eds.), Africa's urban revolution, Zed Books, London, 1-17.

Roberts, D., Boon, R., Diederichs, N., Douwes, E., Govender, N., Mcinnes, A. et al., 2012, 'Exploring ecosystem-based adaptation in Durban, South Africa: "Learningby-doing" at the local government coal face', Environment and Urbanization 24(1), 167-195. http://dx.doi.org/10.1177/0956247811431412

Sala, O.E., Chapin, F.S., Armesto, J.J., Berlow, E., Bloomfield, J., Dirzo, R. et al., 2000, 'Global biodiversity scenarios for the year 2100', Science 287(5459), 1770-1774. $\mathrm{http}: / / \mathrm{dx}$.doi.org/10.1126/science.287.5459.1770

Seto, K., Güneralp, B. \& Hutyrac, L., 2012, 'Global forecasts of urban expansion to 2030 and direct impacts on biodiversity and carbon pools', PNAS 109(40), 16083-16088. http://dx.doi.org/10.1073/pnas.1211658109

Sutherland, C., Sim, V., Buthelezi, S. \& Khumalo, D., 2016, 'Social constructions of environmental services in a rapidly densifying area of eThekwini Municipality', Bothalia: African Biodiversity \& Conservation 46(2). http://dx.doi.org/10.4102/ abc.v46i2.2128

Taylor, C., Cockburn, J., Rouget, M., Ray-Mukherjee, J., Mukherjee, S., Slotow, R. et al., 2016, 'Continuous, reflective evaluation lays the foundation of transdisciplinary research-action partnerships', Bothalia: African Biodiversity \& Conservation 46(2). http://dx.doi.org/10.4102/abc.v46i2.2154

UN-HABITAT, 2010, State of the World's cities 2010/2011 - Cities for All: Bridging the Urban Divide, United Nations Human Settlements Programme (UNHabitat), Nairobi.

van Wyk, A.E. \& Smith, G.F., 2001, Regions of floristic endemism in southern Africa, Umdaus Press, Pretoria. 